\title{
Parental encouragement as an indicator of self-concept of adolescents and its implication in higher education
}

\author{
M.K. RATHORE AND SHEELA SANGWAN
}

Received: 11.08.2015; Revised: 02.11.2015; Accepted: 11.11.2015

See end of the paper for authors' affiliations

\section{M.K. RATHORE}

P.G. Department of Human Development, S.N.D.T. Women's

University, MUMBAI (M.S.) INDIA

Email : manjurathore23@gmail.

com

\begin{abstract}
Through adolescence years, individual forge a personal identity, a self-concept, and an orientation toward achievement and a strong bonding with parents that will play a significant role in shaping their success in school, work, and life. Present study was undertaken to assess the predictors of self-concept and academic achievement of 13-15 year old adolescents and implication of that in higher education. The study was conducted in Hisar district of Haryana state. From each of the four selected schools of rural and urban area of Hisar, all boys and girls of 13-15 year were included in final sample. The results revealed that parental encouragement, residential area, and family relationship with neighbours, age, maternal occupation and adolescents spending time with grandparents as the significant predictors for self-concept of adolescents. Likewise academic class, self-concept, paternal occupation, number of siblings as the significant predictors for academic achievement of adolescents i.e. adolescents who were under parental support and supervision, had comparatively better self worth which ultimately leads a successful academic orientation. Adolescents having good parental support and higher level of self-concept will pursue higher education with great urge.
\end{abstract}

KEY WORDS: : Adolescence, Self-concept, Parental encouragement, Maternal occupation, Higher education, Academic achievement, Support and supervision

- HOW TO CITE THIS PAPER : Rathore, M.K. and Sangwan, Sheela (2015). Parental encouragement as an indicator of self-concept of adolescents and its implication in higher education. Asian J. Home Sci., 10 (2) : 381-385. 